\title{
Newly Identified Anthracnose Resistant French Bean (Phaseolus vulgaris) Accessions from Garhwal Hills of Uttarakhand, India
}

\author{
Deepti Prabha $^{1}$, Navneeti Chamoli ${ }^{1}$, Yogesh Kumar Negi ${ }^{2}$ and J. S. Chauhan ${ }^{1}$ \\ ${ }^{1}$ Department of Seed Science \& Technology, HNB Garhwal University, \\ Srinagar, Garhwal, Uttarakhand, India \\ ${ }^{2}$ Department of Basic Sciences, College of Forestry, (VCSG UUHF), \\ Ranichauri, Tehri Garhwal, Uttarakhand, India \\ *Corresponding author
}

\section{A B S T R A C T}

Keywords

Anthracnose resistance, French bean, Germplasm screening, SCAR markers.

Article Info

Accepted:

20 January 2020

Available Online:

10 February 2020
Anthracnose is one of the major diseases of French bean, which alone causes up to $50 \%$ loss in yield. This disease is very common in cold and humid areas. Use of resistant varieties instead of harmful pesticides is an effective and organic way to protect crop from diseases. Immense diversity of French bean is present in Uttarakhand hills and is required to be explored adequately. French bean germplasm was collected from Garhwal hills of Uttarakhand and screened for anthracnose resistance using SCAR markers. Accession GFB-3 and GFB-30 were found resistant for anthracnose under in-vitro and field conditions as well. Both the accessions showed the presence of multiple resistance genes for anthracnose in them.

\section{Introduction}

Anthracnose is considered as the most common disease of French bean (Phaseolus vulgaris L.), which is caused by Colletotrichum lindemuthianum (Sacc. \& Magnus) Scrib. The disease causes massive loss in crop yield worldwide, preferably in the regions with prevailing high humidity and moderately low temperature $\left(13\right.$ to $\left.27^{\circ} \mathrm{C}\right)$. Wide but unexplored genetic diversity of French bean is available in Uttarakhand hills in western Himalaya (India). The immense genetic diversity of landraces of crops is the most useful and economically valuable part of biodiversity. Unfortunately, very little efforts have been done in this direction.

Considering this disease as the serious constraint to the French bean growth and yield, accessions of French bean were collected from six district of Garhwal regions. All the accessions were screened through invitro pathogenesis assay under controlled 
conditions using $C$. lindemuthianum spore suspension $\left(10^{6}\right.$ conidia/ml $)$ Disease reactions were rated visually using a scale from 1 to 9 . The plants scored from 1 to 3 were considered resistant, whereas the ones scored from as 3.1 to 6 were tolerant and 6.1 to 9 were susceptible.

Disease score of both the accessions was 1.5 (Pastor corrales et al., 1995). Whereas, for amplification of resistance genes, DNA was isolated by using CTAB method following the method of Stewart and Lee (1993). PCR amplification of the genes was performed by using $10 \mu \mathrm{l}$ of reaction mixture containing DNA (50 ng), $2 \mu 1$ 10X PCR Buffer, Primer $(1 \mu \mathrm{M}), \quad \mathrm{dNTP} \quad(1 \mathrm{mM})$ and Taq DNA polymerase $(0.3 \mathrm{U})$ and specific temperature conditions as per manufacturers details.

Four field trials were conducted to test the anthracnose disease incidence at three different locations ranging in between 560 to $2300 \mathrm{~m}$ above mean sea level (Table 1). Data for natural disease development was collected routinely.

\section{Results and Discussion}

Disease reactions were rated visually using a scale from 1 to 9 . The plants scored from 1 to 3 were considered resistant, whereas the ones scored from as 3.1 to 6 were tolerant and 6.1 to 9 were susceptible (Pastor Corrales et al., 1995). Disease score of both the accessions was 1.5 and therefore considered as resistant to the disease. Very few leaf spots (1-3) with slight leaf yellowing was observed on inoculated plants (Fig. 1)

Out of thirteen SCAR primers 8 primers were amplified. Amplified primers were SF10 (Co10), SAS13 ( $\left.\mathrm{Co}^{2} 4^{2}\right)$, SH18 (Co-4 $\left.{ }^{2}\right)$, SAZ 20 (Co-6), SH20 (Co-2), SC 08 (Co-4), SZ 04 (Co-6) and SW 12 (Co-3/Co-9). Accession GFB-30 was amplified with four primers SF10, SAS-13, SH-18 and SZ-04 was found having three genes $\left(\mathrm{Co}-10, \mathrm{Co}-4^{2}, \mathrm{Co}-6\right)$ related to anthracnose resistance. On screening with SCAR markers GFB-3 accession amplified with three primers SF-10, SAS-13 and SZ-04 and was found having three genes $\left(\mathrm{Co}-10, \mathrm{Co}-4^{2}, \mathrm{Co}-6\right)$ related to anthracnose resistance.

Co-10 gene is explained in literature as the most potential gene for marker assisted breeding programme for Brazilian French bean germplasm (Alzate marin et al., 2003) $\mathrm{Co}-4^{2}$ allele is also considered as one of the best resistance source by breeders (Miklas and Kelly, 2002) The both the accessions having $\mathrm{Co}-10$ and $\mathrm{Co}-4^{2}$ gene together were found resistant for anthracnose.

Table.1 Screening of French bean accessions for anthracnose disease under field conditions

\begin{tabular}{|c|c|c|c|c|}
\hline Year & Site/ Location & Period & $\begin{array}{l}\text { Altitude } \\
\text { (a msl) }\end{array}$ & Disease reaction \\
\hline 2016-2017 & $\begin{array}{l}\text { HNB Garhwal University, } \\
\text { Chauras Campus }\end{array}$ & Oct-April & $560 \mathrm{~m}$ & $\begin{array}{l}\text { No disease was reported } \\
\text { in both the accessions }\end{array}$ \\
\hline 2017 & Ranichauri, Tehri Garhwal & April- Sept & $1700 \mathrm{~m}$ & $\begin{array}{l}\text { GFB-3- } 1.0 \\
\text { GFB-30- } 1.25\end{array}$ \\
\hline 2018-2019 & $\begin{array}{l}\text { HNB Garhwal University, } \\
\text { Chauras Campus }\end{array}$ & Oct-April & $560 \mathrm{~m}$ & $\begin{array}{l}\text { No disease was reported } \\
\text { in both the accessions }\end{array}$ \\
\hline 2019 & $\begin{array}{l}\text { Trjuginarayan, } \\
\text { Rudraprayag }\end{array}$ & April- Sept & $2300 \mathrm{~m}$ & $\begin{array}{l}\text { No disease was reported } \\
\text { in both the accessions }\end{array}$ \\
\hline
\end{tabular}


Table.2 Qualitative and quantitative characters of the French bean accessions (GFB-3 and GFB-30)

\begin{tabular}{|c|c|c|c|c|c|c|c|c|c|c|}
\hline $\begin{array}{l}\text { Accessi } \\
\text { on }\end{array}$ & Seed colour & $\begin{array}{l}\text { Flower } \\
\text { colour }\end{array}$ & $\begin{array}{l}\text { Seed } \\
\text { length } \\
(\mathrm{mm})\end{array}$ & $\begin{array}{l}\text { Seed } \\
\text { diameter } \\
(\mathbf{m m})\end{array}$ & $\begin{array}{l}\text { Pod } \\
\text { length } \\
\text { (cm) }\end{array}$ & $\begin{array}{l}\text { Number } \\
\text { of seed } \\
\text { per pod }\end{array}$ & $\begin{array}{l}\text { Pod colour at } \\
\text { physiological } \\
\text { maturity }\end{array}$ & $\begin{array}{l}\text { Days to } 50 \\
\% \\
\text { maturity }\end{array}$ & $\begin{array}{l}100 \\
\text { seed } \\
\text { weight } \\
(\text { gm) }\end{array}$ & $\begin{array}{l}\text { Yield } \\
\text { (gm/ } \\
\text { plant) }\end{array}$ \\
\hline GFB-3 & $\begin{array}{l}\text { White with } \\
\text { light green } \\
\text { spot }\end{array}$ & White & 10.1 & 3.6 & 11.72 & 6.4 & Green & 69 & 29.10 & 102.38 \\
\hline $\begin{array}{l}\text { GFB- } \\
30\end{array}$ & $\begin{array}{l}\text { White with } \\
\text { black spot }\end{array}$ & Purple & 8.4 & 4.2 & 10.94 & 7.6 & $\begin{array}{l}\text { Yellowish } \\
\text { green with red } \\
\text { spots }\end{array}$ & 62 & 25.34 & 26.56 \\
\hline
\end{tabular}

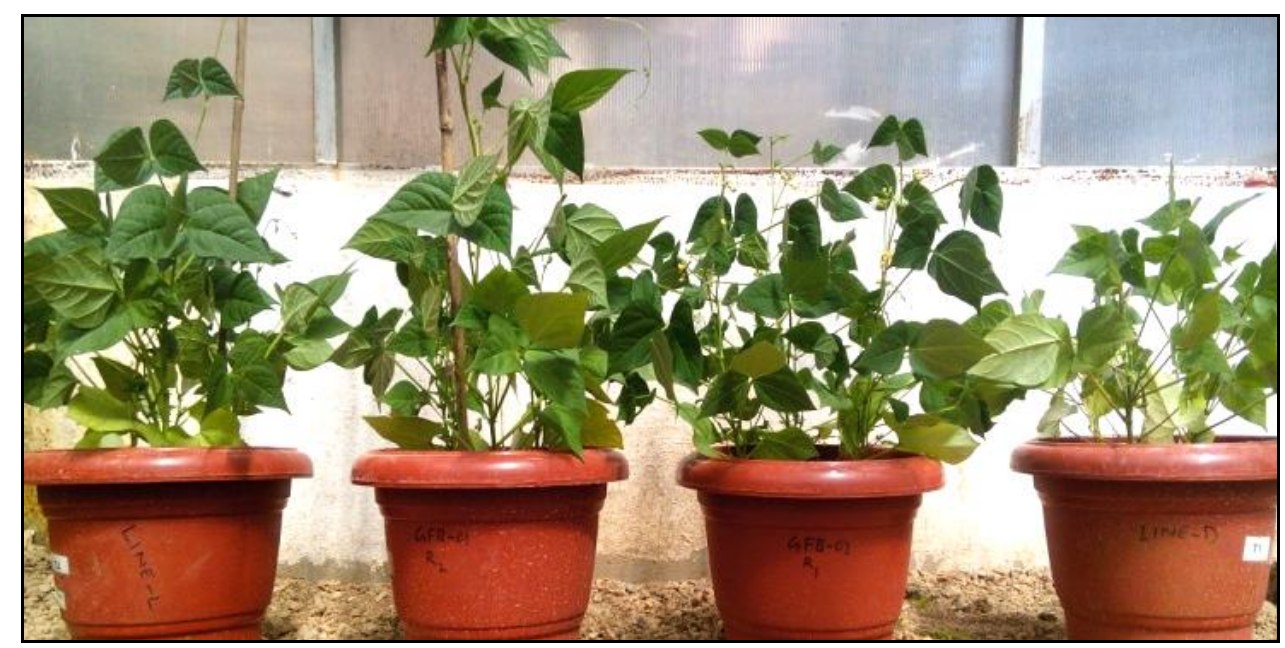

Fig.1 Comparative performance of the line GFB-3 with resistant checks (D and L lines) under controlled conditions

Four field trials were conducted to test the anthracnose disease incidence. These accessions were screened with $\mathrm{D}$ and $\mathrm{L}$ lines (resistant to anthracnose) used as check under field condition. Almost no disease was recorded in field trials except the Ranichauri trial-2017. However, the disease incidence was very low in this trial too (Table- 1 ).

Out of the germplasm screened, these two accessions showed consistent performance in different trials for resistance against incidence of anthracnose. Accession GFB-3 and GFB30 have multiple genes for anthracnose resistance with good qualitative and quantitative characters (Table-2).

A large number of $\mathrm{Co}$-genes are substantiated in the anthracnose differential cultivars and accessions (Melotto et al., 2000). Resistance provided by a single gene breaks up easily so it is needed to pyramid the genes for effective resistance for anthracnose disease.

\section{References}

Alzate-Marin, A.L., Costa, M.R., Arruda, K.M., De Barros, E.G., and Moreira, M.A. 2003. Characterization of the anthracnose resistance gene present in 
Ouro Negro (Honduras 35) common bean cultivar. Euphytica 133, 165-169.

Melotto, M., Balardin, R.S. and Kelly. J.D. 2000. Host-pathogen interaction and variability of Colletotrichum lindemuthianum. p. 346-361. In D. Prusky et al., (ed.) Colletotrichum: Host specifi city, pathology, and hostpathogen interaction APS Press, St.Paul, MN.

Miklas, P.N., and Kelly. J.D. 2002. The use of
MAS to develop bean germplasm possessing $\mathrm{Co}-4^{2}$ gene for anthracnose resistance. Ann. Rep. Bean Improv. Coop. 45,68-69.

Pastor-Corrales, M.A., Otoya, M.M., Molina, A., and Singh, S.P. 1995. Resistance to Colletotrichum lindemuthianum isolates from Middle American and Andean South America in different common bean races. Plant Disease 79, 63-67.

\section{How to cite this article:}

Deepti Prabha, Navneeti Chamoli, Yogesh Kumar Negi, and Chauhan. J. S. 2020. Newly Identified Anthracnose Resistant French Bean (Phaseolus vulgaris) Accessions from Garhwal Hills of Uttarakhand - Short communication. Int.J.Curr.Microbiol.App.Sci. 9(02): 2748-2751. doi: https://doi.org/10.20546/ijcmas.2020.902.312 